\title{
Translating stakeholder pressure into environmental sustainability-Studying HRM practices as mediating role
}

\author{
Muhammad Rafiq \\ North China Electric Power University/ \\ School of Economics and Management, \\ ChangPing district. Changping line, Beijing, China \\ Xing Ping Zhang \\ North China Electric Power University / \\ School of Economics and Management, Beijing, China \\ Jiahai Yuan \\ North China Electric Power University / \\ School of Economics and Management, Beijing, China \\ Mazhar Saroya \\ Superior University, Lahore, Pakistan \\ Shamsa Kanwal \\ Superior University/ \\ School of Management sciences, Lahore, Pakistan.
}

\begin{abstract}
The research contributes towards the surviving exploration of Human Resource management, hereafter referred as HRM practices, depending on the instrumental estimation of the partner weight which leaves an effect on the organizations choices. This examination imagines HRM hones as an arrangement of the administration process that organizations are attempting to actualize keeping in mind the end goal to react the partner weight which influences the ecological manageability of the firms. Partners may apply weight on association's to execute HRM hones which could prompt enhance the ecological manageability. The current study addresses partner weight for the execution of HRM hones inside the organizations. The principle reason for this exploration is to control the partner's weight and to fill the holes occurred by external stakeholder pressure inside the organizations. The study examines the mediating effect of HRM practices with stakeholder pressure and environmental sustainability. This investigation depends on implementing the HRM practices and to control the stakeholder pressure within the firms. This investigation helps the managers to understand the importance of HRM hones. The collection of data is based on the primary and secondary sources. Primary sources are related to the questionnaires and secondary sources are related to the research articles. HR managers can use the result to control the stakeholders' pressure and to improve the environmental sustainability. These findings are used to know about the variables that are creating the gap of communication and to decrease the pressure of stakeholders within the firms. It helps us to execute the new policies and norms within the firms.
\end{abstract}

Key words: HRM practices, stakeholder pressure, environmental sustainability

\section{INTRODUCTION}

Stakeholder pressure is one of the significant and present area of research investigation and important for policy making and for managerial implications. The impact of the partner weight 
on the reception and execution of HRM hones leaves impacts on ecological manageability. Partner weight impacts the authoritative decisions. More specifically, the specialists expect that organizations can utilize HRM hones for reacting to partner weight on the ecological issues and by that for creating firm's natural sustainability (Holzer, 2013). A few creators saw the impacts of shareholder pressure on the company's conduct as moderately practice. Yet few examinations have explored that the investors' weight impact the usage of HRM hones on ecological sustainability. HRM practices could add to overhaul the execution of the laborer's in the organization (Nayyab, et al., 2014). In the past, researchers said that stakeholder pressure not only affects the organizational performance, but also the environmental sustainability (Kassinis, 2013). To lead an observational examination of partner weight the scientists must distinguish the relevant HRM rehearses which impacts the hierarchical sustainability. With regard to partner weight, earlier methodologies were concentrating on the weight by various gatherings (Fassin, 2014). The researchers conceptualize the partner weight on the absence of usage of HRM hones yet additionally impacts the ecological supportability (Berman et al., 2014). In such way the speculation intends to beat two particular learning gaps to be specific to partner weight and natural manageability that leads

For contribution in theory development the researchers are concerned to know that how stakeholder's pressure can lead to improve the ecological sustainability. A number of researchers suggest to look at the role of internal environment, particularly accomplishment of proper policies, norms and rules within the organization (Kassinis, 2015; Preston et al., 2014; Banerjee, 2013) Wehmeyer, 2014). HRM practices have been considered as a key factor in improving the environmental sustainability. Recent studies confirmed that different HRM practices are positively related to the environmental sustainability of the firm (Lozano, 2014). A number of specialists recommend that the association with the higher administration is constantly great since it empowers the firm to satisfy its objectives and goals (Sharma, 2015). Partner weight thus empowers firm to receive the HRM rehearses which are fundamental for each association and it impacts the natural supportability of the firm. Stakeholders doesn't just assume an essential part in embracing the HRM hones yet in addition to improve the ecological maintainability (Paulraj, 2015). The specialists show the partner's weight have specific impacts the HRM studies and natural sustainability that empirically investigate the effect of partner weight on usage of HRM hones. In-fact the connection between partner weight and HRM hones impacts natural manageability (Corbett, 2015)

A few analysts see the impacts of partner weight on the firm conduct relatively predictable. Yet few investigations have explored the unequivocal impact of stakeholder weight on HRM rehearses and natural sustainability. The past examinations suggest that how accomplice weight prompts affect the implementation of HRM hones. To the best of researcher's data a trial examination of the accomplice weight and use of HRM practices has been as yet missing and it affects the internal environment of the firm (Maguire et al., 2015).

The research examines the relationship between the stakeholder pressure and HRM practices within the Energy companies of Punjab. The rationale of this study is to find out the solution for controlling the stakeholder pressure, which affects the environmental sustainability of the firms. It is very important to know that why task efficiency increases with the workload pressure and when firms implement the HRM practices within the firms properly. 


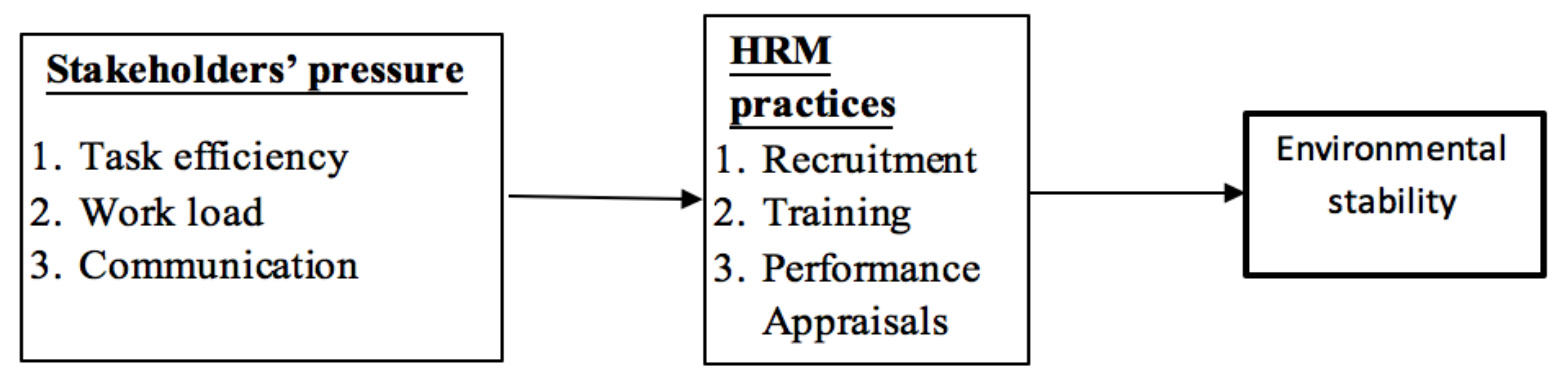

Figure-1; Research Model

\section{LITERATURE REVIEW}

Partners' weight can influence the firm on accomplishing their targets and objectives. Hypothesis of partners, is well recognized and has been utilized as a part of human resource administration. There are two sorts of partners; internal and external. Internal partners are those which work in the association and outer partners are the individuals who are the investors of the firms. Outer partners pressurize the organizations for doing work in short time. By doing this, workload increases in result of a communication gap that occurs with the administration.

\section{Stakeholder pressure and HRM practices:}

The ability and capacity of stakeholders to affect the organization and influence its decisions is known as stakeholders' pressure. Numerous empirical and theoretical evidences are witness to pursue that stakeholder's pressure not only leaves a negative impact on completing the tasks of the firm but also become hurdle in earning profit (John et al., 2014). Previous researchers' contribution with respect to examining the relationship between stakeholders' pressure and environmental sustainability in minute and mediating role of HRM practices is also in dearth. External stakeholders' opinion damages firms repute by influencing public opinion at large, it may have direct influence on implication of HRM practices. The contribution in theory development, emerging researchers are interested in understanding that how stakeholders' pressure can progress forward to better environment (Horizon et al., 2013).

The consistency among stakeholder pressure and HRM practices are setting results in execution of these practices within the firms. We expect that associations can use HRM practices to offer response to accomplice's weights on common issues and by that for developing firm natural practicality (Jackson et al., 2014). This supposition is in the line of limited game plan generally examines the degree of HRM practices. Research on HRM practices deals with moving past as far as possible to examine outside weights that shape the HR practices for the firms. The specific field of HRM examines to appreciate the association between partner weight and HRM practices. HRM properly investigates the use of accomplice's speculation remembering the true objective to improve the perception of HRM practices within the organization (Taylor et al., 2015). Particularly previous researchers suggested to shape the HRM practices of the firms. A couple of examinations has been displayed the key effect of managerial accomplices on the execution of HRM practices. HRM practices sharpens a positive and direct effect on the execution of laborers (Pawee, 2014). HRM practices associate the stakeholder pressure and to what reason such practices increase the biological viability. Meanwhile our dedication is appropriate for the HRM practices and for policy makers who wants to implement the policies within the firms. We also give some suggestions to HR managers and a specialist for arranging interests in HRM sharpens. Besides we offer confirmation to course of action makers and regulatory workplaces of the ampleness of HRM sharpens which may outline specific headings and in a result drive a firm HRM practice assurance. To our best knowledge the examination of association between the accomplice's weight and use of HRM sharpens are up 'till now insufficient. This is to a great degree 
surprising in light of the fact that accomplice theory even in the work by partners has been comprehensively seen to be a key speculation for understanding why firms grasp and realize specific HRM practices (Greenwood et al., 2015). HRM practices investigate accomplice's speculation has been ended up by learning in making policies and rules within the firms (Shuling, 2015). Stakeholder pressure composes three essential inspirations to grasp an accomplice framework which is animated by the estimations of previous researchers. The first reason is associated with the estimation of accomplice's speculation on the managerial one as clearly conveyed. This decide the effectiveness of the firms to deal with each and every critical accomplice is as legitimate for administering HRM practices for other organization endeavors, human resource practices can't be implemented without a doubt to address the issues (Simmons ,2016).

\section{Human Resource Management Practices:}

World is heading towards a stiff competition with unstable environment ever before, especially energy based firms are facing multifaceted discrepancies. They need an integrated and coherent HR system to gain a competitive advantage (Sparrow et al., 2014). According to Daley (2013) 'HRM practices a course of action used for the relationship to direct HR through empowering the change of capacities that are firm specific, convey convoluted social association and make affiliation data to help high ground'. Past examination revealed that HRM practices which are related to the affiliation progression, basically based on the "general" or "best practice" approach. A review of the written work displays that three fundamental practices that have been connected with improvement, joining enlistment, planning and execution assessment (Lauren \& Foss, 2015). The researchers contended that administrators and directors ought not to overlook the significance of HRM rehearses on satisfying the desires of their workers in regards to their tasks. In general HRM practices can be closed as an instrument actualized inside the organizations with a specific end goal to control the partner weight and to enhance ecological suitability.

\section{Recruitment}

Hiring is characterized as procedure of producing the pool of fit individuals to apply for work inside the organizations be that as it may, then again enlistment is demonstration of choosing at least one individuals from the gathering. Past analysts bolster the enlistment procedure and furthermore help to direct for the meetings. The enlistment part gives the fundamentals to a main detail (Smith et al., 2014). There are two sorts of enrollment: Internal recruitment, which directly depends upon internally which check person for job within the firm, External recruitment, which depends upon externally which check the person for job outside the firm, HRM hones accentuate on the procedure of enrollment which depends on the layout of the interviews. Recruitment strategies in the mechanical area may offer bits of knowledge into the procedure associated with setting up the enlistment policies (John et al., 2014). Recruitment is a fundamental part in HRM practices something that do routinely as practices and moreover real into your moral guidelines to do work or some extraordinary activities that you make as a bit of you are appearing with respect to the experience. Recruitment is described as the, gathering pool of capable candidates for better hiring process. Employers use different ways through which they recruit like; email, telephone and advertising. What's more lacking in enrollment may come about into the blocks in the administration, leadership and in general enlistment, process would itself be able to be progressed and revised by agreeing to administration approaches. Along these lines any industry is encouraged to grow ongoing enlistment methodologies that must endeavor to create a pool of suitably qualified and all around experienced people in order to adequately imitate the enrollment procedure. (Wizeler 
et al., 2015; Newell, 2015; Osmeke, 2015; Taher et al., 2014; Fey Carlf, 2014; Sinha, 2013; Gould, 2013).

Complying with employment opportunities, recruitment ensures justice and fair treatment with all the applicants (Sherman, 2016). The quality of HR in firms is highly dependent on the quality of applicants attracted because firm is going to select employees from those who were attracted (Gamage,2014). Recruitment forms a major part of the firms overall strategies which identifies and secures people need for the firm to survive and to get success (Elwood, 2012). After successful induction of new comers, it is pivotal to climates them, feel them fit for job and enhance their skills for current job (Smith et al, 2014). Training is crucial but important part to do all these tasks. Hence it is important to understand the soul of training which can deliver its best.

\section{Training:}

Training proves to be a gauge of the employees for achieving the firm's objectives and goals. Training is the systematic development of knowledge, skills and attitudes required by individual to perform a task or job adequately (Michael Armstrong, 2014). The need of training programs is dependent on the requirement of job profiles. Training should be conducted in a systematic order so as to derive benefits from it. The training system involves four stages, namely: first, training needs assessment (TNA). Second, design the training programs. Third, deliver the training program. Four, implement \& evaluate the training program.

Distinctive HRM rehearses are followed in the diverse firms as well, so the need of the preparation relies upon the prerequisites of employment profile. Training is the key procedure that is applicable and valuable data that educates members and build up the skills (Kane, 2013). Training is one of the basic of HRM practice as it can enhance the execution of workers inside the firms. Moreover, training is the change of the learning, enhancement of capacities and perspectives required by an individual for accomplishment of a specific job adequately (Rashmi Dewangan, 2014; Edwin B Flippo, 2013).

Training presents a prime opportunity to expand the learning base of the extensive number of specialists, getting projects ready for all agents at all levels. The instructional meeting and activities for new agents should fuse a presentation program which engages the laborers to understand the methodologies of the association. A readiness program empowers the new delegates to support their abilities that each specialists need to advance. Getting ready may in like manner, gathers the laborer's conviction. Planning undertakings may push delegates to perform by a long shot better and help them than consider new surveys (Perron et al., 2012). Training a key part in every affiliation, these programs upgrade the execution of delegates at workplace. Training redesign the general execution of the specialist in a relationship in different ways. Training program improved the idea of delegate's life on the work put (Rao, 2012). Getting ready is stressed over presenting specific capacities for a particular reason. Getting ready is the progression of taking in a gathering of redid lead (Mani et al., 2014; Sheppard, 2013). It is extremely vital for every worker to go to the instructional courses. Prepared workers perform well when contrasted with untrained representatives (Gordon, 2014). Particularly preparing creates abilities, competency and capacity to enhance the execution of representatives. Preparing programs are in the stimulant that workers require to enhance their execution and abilities (Amir, 2013; Chris, 2013). The primary point of the preparation is to enhance the important aptitudes with a specific end goal to help the organizations in accomplishing their objectives and make an upper hand and to enhance the overall efficiency of employees (Qaiser, 2014). 


\section{Performance Appraisal:}

Performance appraisal is a systematic way of measuring and evaluating job related activities of employees during a specific time frame (Ahmed and Ali; 2012). Based upon the present conditions association are concentrating and using performance appraisal as HRM rehearse execution, evaluation (Ikramullah shah, 2015). In fact, it has been utilized as a tool during the time spent execution evaluation for improving the execution of representative, appropriating prizes and upgrade competencies. In expansion the association can find the worker's quality and improvement needs. Although it is exorbitant to lead execution examination associations. Therefore, the execution assessment rehearse is a characteristic and indivisible piece of the organization (Poursafar, Rajeepour \& Seyadat, 2013). A few investigations bolster the idea that impression of reasonableness of execution examination is as of now firmly identified with the representative's execution in association (Shigutu \& Tensay, 2014). Subsequently, it is imperative for the association to know about worker's view of the execution assessment and to make changes in it, since execution examination has a productive part in changing representative's state of mind (Robert, 2014; Jabbar et al., 2015).

\section{HRM practices and Environmental sustainability:}

Environmental sustainability is defined as, it identifies HRM practices more successful over other firms to promote their practices. Recent research on environmental sustainability suggests that the firms should implement HRM practices within the firms in order to improve the environment (Seuring and Gold, 2014). Previous researchers discussed that ecological sustainability is incomplete without understanding the rules and policies that are implemented within the firms. Hence, the present research analyzes that HRM practices are a set of practices which play an important role in shaping the firms goals and strategies and it help to improve the ecological sustainability of the firms (Amini \& Bienstock, 2015). Many perspectives of environmental sustainability and HRM practices have evolved over time in recent era. Although it investigates that the internal environment of the firm should be properly monitored in order to avoid errors and prevent the firm from fraud. Current researchers suggested that the firms should improve environmental sustainability only if they implement HRM practices. Many firms, addresses that the environmental sustainability requires firms to change their policies, rules, norms and strategies (Scott, 2015).

Previous researches have neglected this fact that why firms are not interested in implementing the HRM practices which are more responsible towards ecological implications. Many perspectives of ecological sustainability have evolved over times (Pujari et al., 2015). Previous researchers studied the link between HRM practices and environmental sustainability, they argued that in order to control the problems which occurs in making the new policies and rules for the firms, should be solved by implementing HRM practices within the firms. The studies argued that the managers are not making the new policies for the firms which effect the ecological manageability. The Energy industries, addressing the environmental sustainability, requires the changes in the internal environment including values, norms, beliefs and rules which together associated with the firms resources (Scott,2014).

Current research on the environmental sustainability suggests that the firms have to implement HRM practices so that the new policies and rules are introduced to monitor the internal and external environment and to prevent the firm from any kind of loss. Practitioners and policy makers suggested that these two play a very important role in monitoring and evaluating the internal environment (Gioia et al., 2015). 


\section{METHODOLOGY}

The study incorporates the positivism paradigm. The positivism paradigm explores that the reality is based on quantitative measures. According to positivists, true knowledge is based on the experience of senses can be obtained by observation and experiment. The term positivism is to reflect the empirical approach in that claims about knowledge which is directly based on experience (Croty, 2000).

\section{Sample selection and data collection}

The sample is the representation part of the larger population. According to Kothari et al., (2006) the formula for calculating sample size is: $Z 2 * p(1-p) / e 2$. Where $z=1.6384, p=0.25$, e2 $=0.0016$

Based on this formula sample size is 250. According to (Cochn et al., 2015) the sample size above 200 is very good. Stratified sampling is most common for large populations. Stratified sampling is used to select the HR managers from HR department of power production firms. Stratification is the process to divide the total population into sub population. It is used when the population is divided into strata. Stratified random sampling is very near to random sampling.

The strategy of survey is adopted for collecting the data. This strategy is based on the questionnaires which were selected for this research for achieving the accurate results. Questionnaires are based on the strategy of survey and it was used to collect the data from the Energy companies which are working in Punjab. Due to the shortage of time, data are collected from the Energy companies which are working in Punjab. Structured questionnaire is used to collect the primary data from the selected sample. As Jiya et al., (2012) suggested that the policy of survey is very useful for collecting the data in the quantitative research.

\section{Analysis of Data:}

Table-1: Respondents Profile

\begin{tabular}{|l|c|c|}
\hline \multicolumn{1}{|c|}{ Demography } & Frequency & Percentage \\
\hline GENDER (N=250) & & \\
\hline Female & 134 & 54 \\
\hline Male & 116 & 46 \\
\hline AGE (N=250) & 111 & 45 \\
26-35years & 93 & 37 \\
36-45years & 46 & 18 \\
45-55 years & 146 & 58 \\
\hline Designation (N=250) & 104 & 42 \\
HR managers & & \\
Senior Mangers &
\end{tabular}

There were 134 females (54\%) and 116 males (46\%) in this study as a participant. 45\% participants were less than 25 years, while $37 \%$ were between $26-35$ years of age. This study also focuses on the designations of people, as 58\% respondents were HR mangers and $42 \%$ were senior managers. 
Table-2: Descriptive Statistics

\begin{tabular}{|c|c|c|c|c|c|}
\hline Items & $\mathbf{N}$ & Min. & Max. & Mean & $\begin{array}{c}\text { Std. } \\
\text { Deviation }\end{array}$ \\
\hline $\begin{array}{l}\text { Stakeholder pressure is related with the environmental } \\
\text { matters and the degree of the proactivity of organizational } \\
\text { strategies }\end{array}$ & 250 & 1.00 & 5.00 & 3.5920 & 1.29625 \\
\hline Stakeholder pressure is perceived by the managers & 250 & 1.00 & 5.00 & 3.3720 & 1.01871 \\
\hline $\begin{array}{l}\text { Stakeholders pressure effect the performance of the } \\
\text { employees within the organization }\end{array}$ & 250 & 1.00 & 5.00 & 3.7920 & 1.04360 \\
\hline $\begin{array}{l}\text { Stakeholder pressure is the capacity and ability of } \\
\text { stakeholders to effect organization by influencing its } \\
\text { organizational decisions. }\end{array}$ & 250 & 1.00 & 5.00 & 3.6600 & 1.13382 \\
\hline $\begin{array}{l}\text { Stakeholder pressure is of significant contemporary interest } \\
\text { and important to the policymakers, public opinion and } \\
\text { practicing managers. }\end{array}$ & 250 & 1.00 & 5.00 & 3.6280 & .87446 \\
\hline $\begin{array}{l}\text { Task efficiency is a performance indicator that shows a ratio } \\
\text { between the planned and actual values relative to certain } \\
\text { task or job. }\end{array}$ & 250 & 1.00 & 5.00 & 3.7040 & .99415 \\
\hline $\begin{array}{l}\text { In order to increase the task efficiency of employees, a task } \\
\text { management program is required. }\end{array}$ & 250 & 1.00 & 5.00 & 3.7960 & .82286 \\
\hline $\begin{array}{l}\text { Task efficiency can be increased with the help of stream line } \\
\text { processes which allows the organization to earn profit. }\end{array}$ & 250 & 1.00 & 5.00 & 3.8160 & 1.15389 \\
\hline $\begin{array}{l}\text { Proper communication regarding work among team } \\
\text { members can increase the task efficiency. }\end{array}$ & 250 & 1.00 & 5.00 & 3.4520 & 1.20562 \\
\hline $\begin{array}{l}\text { Research shows that mobile technology can increase task } \\
\text { efficiency. }\end{array}$ & 250 & 1.00 & 5.00 & 4.1240 & 1.17051 \\
\hline ork load causes illness for staff & 250 & 1.00 & 5.00 & 2.8960 & 1.38740 \\
\hline $\begin{array}{l}\text { Feel heavy work load. Consider yourself to be in a high } \\
\text { pressure situation. }\end{array}$ & 250 & 1.00 & 5.00 & 3.0880 & 1.52102 \\
\hline $\begin{array}{l}\text { There is sufficient time to complete the work most } \\
\text { effectively }\end{array}$ & 250 & 1.00 & 5.00 & 3.4520 & 1.15108 \\
\hline Working pressure causes trouble for the staff. & 250 & 1.00 & 5.00 & 3.5160 & 1.14147 \\
\hline Work load is the cause of stress and tension. & 250 & 1.00 & 5.00 & 3.6600 & 1.21916 \\
\hline $\begin{array}{l}\text { Management communicate employees duties and control } \\
\text { responsibilities in effective manner }\end{array}$ & 250 & 1.00 & 5.00 & 3.5560 & 1.07866 \\
\hline $\begin{array}{l}\text { Communication channels established for people to report } \\
\text { suspected improprieties. }\end{array}$ & 250 & 1.00 & 5.00 & 3.4000 & 1.01396 \\
\hline $\begin{array}{l}\text { Management take timely and appropriate follow up actions } \\
\text { on communication received from regulators or external } \\
\text { parties. }\end{array}$ & 250 & 1.00 & 5.00 & 4.1800 & .60420 \\
\hline There is good communication in my group. & 250 & 2.00 & 5.00 & 4.5680 & .72073 \\
\hline $\begin{array}{l}\text { There are opportunities available to me to express my ideas } \\
\text { to the upper management. }\end{array}$ & 250 & 1.00 & 5.00 & 3.3680 & 1.54990 \\
\hline $\begin{array}{l}\text { Moral of existing employees can be lowered due to poor } \\
\text { process of recruitment. }\end{array}$ & 250 & 1.00 & 5.00 & 3.6360 & 1.15448 \\
\hline $\begin{array}{l}\text { The recruitment process helps in identifying the competence } \\
\text { both visible like knowledge and skill. }\end{array}$ & 250 & 1.00 & 5.00 & 3.9120 & 98189 \\
\hline $\begin{array}{l}\text { Dedication of employees towards performance can increase } \\
\text { due to fair practices in recruitment. }\end{array}$ & 250 & 1.00 & 5.00 & 3.1440 & 1.11004 \\
\hline There is vast scope in current process of recruitment. & 250 & 2.00 & 5.00 & 4.3320 & .83940 \\
\hline $\begin{array}{l}\text { Advanced tools and techniques will enhance success rate of } \\
\text { recruitment. }\end{array}$ & 250 & 1.00 & 5.00 & 3.6640 & 1.22192 \\
\hline $\begin{array}{l}\text { My organization has a training policy applicable to all } \\
\text { employees. }\end{array}$ & 250 & 1.00 & 5.00 & 2.7600 & 1.33474 \\
\hline
\end{tabular}


Supervisors tell that whether they are doing their job as per the training imparted or not.

When employees arrive for training supervisors encourage them to share what they have.

Supervisors make sure that employers have the opportunity to use their training immediately.

Employees who use their training are given preference for new assignments.

Supervisors ease the pressure of work for a short time so that the employees have a chance to practice new skills that are taught in training.

I am motivated to learn the concepts that will be covered in training programs

Extensive training programs are provided for employees in a firm.

Performance appraisal system is needed in the organization Satisfied with existing performance appraisal system.

The performance appraisal helps to win cooperation and team work.

Promotion is purely based on performance appraisal.

Performance appraisal increases employees motivation

Performance appraisal is helpful in reducing the grievance of

employees

The performance appraisal system helps to identify the

strength and weakness of the employees.

Identify HRM practices successfully implemented by other

companies recognize them for efforts and promote their

practices.

Serve as an advocate for environmental sustainability from a

business perspective on the local level.

Provide its members with the information about cost

effective environmental friendly business.

\begin{tabular}{|c|c|c|c|c|}
\hline 250 & 1.00 & 5.00 & 3.9880 & 1.23367 \\
\hline 250 & 1.00 & 5.00 & 3.2280 & 1.44234 \\
\hline 250 & 1.00 & 5.00 & 3.7480 & 1.10698 \\
\hline 250 & 1.00 & 5.00 & 3.2360 & 1.23059 \\
\hline 250 & 1.00 & 5.00 & 3.2920 & .98111 \\
\hline 250 & 1.00 & 5.00 & 3.6160 & .89428 \\
\hline 250 & 1.00 & 5.00 & 3.6480 & 1.29414 \\
\hline 250 & 1.00 & 5.00 & 3.4440 & 1.43075 \\
\hline 250 & 1.00 & 5.00 & 3.1760 & 1.27732 \\
\hline 250 & 1.00 & 5.00 & 3.8160 & 1.24432 \\
\hline 250 & 1.00 & 5.00 & 3.3880 & .91696 \\
\hline 250 & 1.00 & 5.00 & 3.8200 & 1.09196 \\
\hline 250 & 1.00 & 5.00 & 3.3520 & 1.46858 \\
\hline 250 & 1.00 & 5.00 & 3.0440 & 1.61633 \\
\hline 250 & 1.00 & 5.00 & 3.9760 & 1.09371 \\
\hline 250 & 1.00 & 5.00 & 3.9920 & 1.41135 \\
\hline
\end{tabular}

In stakeholder pressure highest mean value is (3.6280 to 3.5920) and standard deviation value is from (1.29625 to .87446). In task efficiency highest mean value is (4.1240 to 3.7040) while standard deviation value is from (1.17051 to .99415). In workload highest mean value is (3.6600 to 2.8960), standard deviation value is from (1.38740 to 1.21916$)$. In communication highest mean value is (4.5680 to 3.3680$)$, standard deviation value is from (1.54990 to 1.01396). In recruitment highest mean value is (4.3320 to 3.1440), standard deviation value is from (1.15448 to .83940). In training highest mean value is (3.9880 to 2.7600), standard deviation value is from (1.44234 to .89428). In performance appraisal the highest mean value is from (3.8200 to 3.1760), standard deviation is from (1.46858 to .91696). In environmental sustainability highest mean value is from (3.9920 to 3.0440), standard deviation value ranges from (1.61633 to 1.09371 ). 


\section{Table-3: Factor Loading}

\begin{tabular}{|c|c|}
\hline \multicolumn{2}{|l|}{ Stakeholder pressure } \\
\hline Stakeholders pressure effect the performance of the employees within the organization & .294 \\
\hline $\begin{array}{l}\text { Stakeholder pressure is the capacity and ability of stakeholders to effect organization by } \\
\text { influencing its organizational decisions. }\end{array}$ & .502 \\
\hline $\begin{array}{l}\text { Stakeholder pressure is of significant contemporary interest and important to the } \\
\text { policymakers, public opinion and practicing managers. }\end{array}$ & .531 \\
\hline \multicolumn{2}{|l|}{ Task efficiency } \\
\hline $\begin{array}{l}\text { Task efficiency is a performance indicator that shows a ratio between the planned and } \\
\text { actual values relative to certain task or job. }\end{array}$ & .536 \\
\hline $\begin{array}{l}\text { Task efficiency can be increased with the help of stream line processes which allows the } \\
\text { organization to earn profit. }\end{array}$ & .286 \\
\hline $\begin{array}{l}\text { Proper communication regarding work among team members can increase the task } \\
\text { efficiency. }\end{array}$ & .523 \\
\hline \multicolumn{2}{|l|}{ Workload } \\
\hline Heavy work load causes illness for staff & .387 \\
\hline Feel heavy work load. Consider yourself to be in a high pressure situation. & .432 \\
\hline Working pressure causes trouble for the staff. & .411 \\
\hline There is sufficient time to complete the work most effectively & .493 \\
\hline \multicolumn{2}{|l|}{ Communication } \\
\hline Communication channels established for people to report suspected improprieties. & .497 \\
\hline $\begin{array}{l}\text { Management communicate employees duties and control responsibilities in effective } \\
\text { manner }\end{array}$ & .497 \\
\hline \multicolumn{2}{|l|}{ Recruitment } \\
\hline Moral of existing employees can be lowered due to poor process of recruitment. & .420 \\
\hline $\begin{array}{l}\text { The recruitment process helps in identifying the competence both visible like knowledge } \\
\text { and skill. }\end{array}$ & .495 \\
\hline $\begin{array}{l}\text { Dedication of employees towards performance can increase due to fair practices in } \\
\text { recruitment. }\end{array}$ & .423 \\
\hline There is vast scope in current process of recruitment. & .423 \\
\hline \multicolumn{2}{|l|}{ Training } \\
\hline $\begin{array}{l}\text { Supervisors make sure that employers have the opportunity to use their training } \\
\text { immediately. }\end{array}$ & 656 \\
\hline I am motivated to learn the concepts that will be covered in training programs & .656 \\
\hline \multicolumn{2}{|l|}{ Performance Appraisal } \\
\hline Performance appraisal system is needed in the organization & .419 \\
\hline Satisfied with existing performance appraisal system. & .400 \\
\hline The performance appraisal helps to win cooperation and team work. & .436 \\
\hline $\begin{array}{l}\text { Promotion is purely based on performance appraisal. Performance appraisal increases } \\
\text { employees motivation }\end{array}$ & .403 \\
\hline \multicolumn{2}{|l|}{ Environmental Sustainability } \\
\hline $\begin{array}{l}\text { Identify HRM practices successfully implemented by other companies recognize them for } \\
\text { efforts and promote their practices. }\end{array}$ & 679 \\
\hline $\begin{array}{l}\text { Serve as an advocate for environmental sustainability from a business perspective on the } \\
\text { local level. }\end{array}$ & 679 \\
\hline
\end{tabular}

As suggested by Straub et al., (2004), factors loading values should always be greater than 0.40, hence all are good. Here my value ranges from (.400-.679). According to the output criterion validity is met. It proves that instrument is valid through which data is collected. 


\section{Factor Analysis}

Table-4: KMO and Bartlett's Test

\begin{tabular}{|l|c|c|c|c|}
\hline \multicolumn{1}{|c|}{ CONSTRUCTS } & $\begin{array}{c}\text { NO. OF } \\
\text { ITEMS }\end{array}$ & $\begin{array}{c}\text { KMO } \\
\text { MEASURE OF } \\
\text { SAMPLE } \\
\text { ADEQUACY }\end{array}$ & $\begin{array}{c}\text { BARTLETT'S } \\
\text { TEST OF } \\
\text { SPHERICITY } \\
\text { CHI-SQUARE }\end{array}$ & $\begin{array}{c}\text { BARTLETT'S } \\
\text { TEST OF } \\
\text { SPHERICITY } \\
\text { SIG. }\end{array}$ \\
\hline Stakeholder pressure & 3 & 0.630 & 88.226 & .000 \\
\hline Task efficiency & 3 & 0.637 & 71.035 & .000 \\
\hline Workload & 4 & 0.613 & 500.079 & .000 \\
\hline Communication & 3 & 0.606 & 50.090 & .000 \\
\hline Recruitment & 5 & 0.743 & 434.890 & .000 \\
\hline Training & 2 & 0.600 & 6.541 & .000 \\
\hline Performance Appraisal & 4 & 0.653 & 379.207 & .000 \\
\hline $\begin{array}{l}\text { Environmental } \\
\text { Sustainability }\end{array}$ & 2 & 0.600 & 1.730 & .000 \\
\hline
\end{tabular}

KMO measures the validity of data, further analysis is run if data is valid, 0 to 1 is the value of KMO. 0 shows that there is no application so, factor analysis becomes inappropriate, 1 depicts the good validity of data and further analysis is done. The table shows that all the values are at an acceptable level, the level of acceptability is 0.6. For stakeholder pressure the value of KMO $=(0.630)$, for task efficiency $\mathrm{KMO}=(0.637)$, for workload $\mathrm{KMO}=(0.613)$, for communication $\mathrm{KMO}=(0.606)$, for recruitment $\mathrm{KMO}=(0.743)$, for training $\mathrm{KMO}=(0.600)$, for performance appraisal $\mathrm{KMO}=(0.653)$, for environmental sustainability $\mathrm{KMO}=(0.600)$ respectively and all the values are constructing. All values show significant values in this table (Hutcheson \& Sofroniou, 1999).

The significance of relationship between items of construct is checked through Sphercity of Bartlett's test. Further factor analysis cannot be proceeded if there is no relationship between the constructs. The table-4 indicates a significant relationship among items so, further analysis is possible.

Table-5: Eigen Values and total variance explained

\begin{tabular}{|c|c|c|c|c|}
\hline \multirow[b]{2}{*}{ CONSTRUCT } & \multirow[b]{2}{*}{ COMPONENTS } & \multirow[b]{2}{*}{ TOTAL } & \multicolumn{2}{|c|}{ INITIAL EIGENVALUES } \\
\hline & & & $\begin{array}{c}\% \text { Of } \\
\text { Variance } \\
\text { Explained }\end{array}$ & $\begin{array}{l}\text { Cumulative } \\
\% \text { Of Variance } \\
\text { Explained }\end{array}$ \\
\hline Stakeholder pressure & COMP 1 & 1.610 & 53.658 & 53.658 \\
\hline Task efficiency & COMP 1 & 1.555 & 57.828 & 57.828 \\
\hline Workload & COMP 1 & 2.418 & 60.440 & 60.440 \\
\hline Communication & COMP 1 & 1.460 & 48.676 & 48.676 \\
\hline Recruitment & COMP 1 & 2.776 & 55.522 & 55.522 \\
\hline Training & COMP 1 & 1.161 & 58.075 & 58.075 \\
\hline Performance Appraisal & COMP 1 & 2.519 & 62.984 & 62.984 \\
\hline Environmental Sustainability & COMP 1 & 1.083 & 54.173 & 54.173 \\
\hline
\end{tabular}

\section{Eigenvalues and total variance explained:}

If Eigen values are greater than 1 they are considered as principle and are used for further analysis. The above table- 5 contains all Eigen values and also show total variance explained for the constructs. Stakeholder pressure (consisted of 5 items explaining 53.68\% variance ) Task 
efficiency (consisted of 5 items explaining 57.828\% variance), Workload (consisted of 5 items explaining 60.440\% variance), Communication (consisted of 5 items explaining 48.676\% variance), Recruitment (consisted of 5 items explaining 55.22\% variance), Training (consisted of 8 items explaining 58.065\% variance), Performance appraisal (consisted of 6 items explaining $62.984 \%$ variance) and environmental sustainability (consisted of 3 items explaining $54.173 \%$ variance).

\section{Regression Analysis:}

Table-6: Multiple Regression Analysis

\begin{tabular}{|c|c|c|c|c|}
\hline \multirow[b]{3}{*}{$\begin{array}{l}\text { INDEPENDENT } \\
\text { VARIABLES }\end{array}$} & \multicolumn{4}{|c|}{ 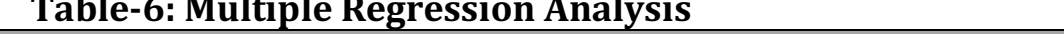 } \\
\hline & \multicolumn{4}{|c|}{ DEPENDENT VARIABLE -- Environmental sustainability } \\
\hline & MODEL 01 & MODEL 02 & MODEL 03 & MODEL 04 \\
\hline Training & $\begin{array}{l}0.093 \\
1.644\end{array}$ & $\begin{array}{l}0.095 \\
1.624\end{array}$ & $\begin{array}{l}0.126 \\
2.266\end{array}$ & $\begin{array}{l}0.316 \\
5.676\end{array}$ \\
\hline Recruitment & $\begin{array}{c}0.08 \\
(1.524)\end{array}$ & $\begin{array}{l}.118 \\
2.198\end{array}$ & $\begin{array}{l}0.128 \\
2.371\end{array}$ & $\begin{array}{l}0.126 \\
2.266\end{array}$ \\
\hline Performance appraisal & $\begin{array}{c}0.155 \\
2.70 \\
\end{array}$ & $\begin{array}{c}0.776 \\
21.231 \\
\end{array}$ & $\begin{array}{c}0.416 \\
7.89 \\
\end{array}$ & $\begin{array}{l}0.059 \\
1.016 \\
\end{array}$ \\
\hline Stakeholder pressure & $\begin{array}{l}0.371 \\
6.364 \\
\end{array}$ & - & - & - \\
\hline Task efficiency & - & $\begin{array}{c}0.403 \\
(7.117) \\
\end{array}$ & - & - \\
\hline Workload & - & - & $\begin{array}{l}3.990 \\
6.464 \\
\end{array}$ & - \\
\hline Communication & - & - & - & $\begin{array}{l}0.372 \\
6.664 \\
\end{array}$ \\
\hline ADJ R2 & 0.004 & 0.011 & 0.017 & 0.089 \\
\hline D.W & 1.77 & 1.76 & 1.78 & 1.71 \\
\hline F.STATS & $\begin{array}{c}1.374 \\
(0.000) \\
\end{array}$ & $\begin{array}{c}1.057 \\
(0.000) \\
\end{array}$ & $\begin{array}{c}1.036 \\
(0.000) \\
\end{array}$ & $\begin{array}{c}1.318 \\
(0.000) \\
\end{array}$ \\
\hline VIF & 1.000 & 1.000 & 1.000 & 1.000 \\
\hline
\end{tabular}

The multiple regression test is applied to verify the mediating effect between independent and dependent variables. The above results in table- 6 shows that there is autocorrelation between the variables. Therefore the adjusted $r$ square is shown as $0.004,0.011,0,017,0,089$ respectively and value of $F$. stats which are 1.374, 1.057,1.036,1.318 respectively determines that all the $p$ values are (0.000).VIF shows the multi collinearity among variables.

\section{DISCUSSION OF THE MAIN FINDINGS}

The results show that different HRM practices (i.e. recruitment, training and performance appraisal) completely mediates the relation between stakeholder pressure and environmental sustainability. Stakeholder pressure leaves a negative impact on the implementation of HRM practices which in return affects the environmental sustainability of the firm. However, stakeholders' pressure can decrease the performance of doing work and increases the communication gap between supervisors and employees. The main discussion is to investigate that why the stakeholders' pressure effect the implementation of HRM practices and how the internal environment should be improved? The results negate the previous studies' findings such as, Stakeholder pressure have different effects on HRM practices and environmental 
sustainability. Additionally previous studies were based on the mediating role of HRM practices in relation with stakeholder pressure and environmental performance. As per explanation of the current results, firms are not interested in the implementation of HRM practices which disturbs the internal environment of the firm.

As a result, the study proposes that stakeholders' pressure may affect the implementation of HRM practices and negatively respond to the environmental sustainability. Concerning about policy makers and practitioners the debate regarding the implementation of HRM practices is very necessary because HRM practices regarding recruitment only does not lead the firm to improve the environmental sustainability. Therefore, considering the mediating role it is proven that the firms are losing the opportunity to control the stakeholder pressure via HRM practices. In order to exploit the possibility, policy makers and practitioners should reconsider the nature of stakeholder pressure, which effects the implementation of HRM practices.

Finally, in order to control the stakeholders' pressure and to fill the gap, the current study, findings emphasize the need for the broader explanation of the mediating role of HRM practices and environmental sustainability. In particular, the current study results might helpful for the policy makers and practitioners regarding the implementation of HRM practices. Proper implementation of HRM practices within the firms may respond to the stakeholders' pressure and helps the firm to achieve its desired goals and objectives.

\section{CONCLUSION \& RECOMMENDATIONS}

Stakeholders' pressure is associated with the implementation of HRM practices and leaves a negative impact on the internal environment. The first thing is related to the concept of implementing the HRM practices, indeed it is very important for the HRM system to adopt it. It does not include any work practices such as teamwork. Secondly, the current study is focused on HRM practices by examining the managers' point of view. It seems that the Energy companies are responsible for not implementing the HRM practices as these practices are very necessary for the firms' survival. The firms are biased towards the candidates at the time of employment. They give preference to referral candidates. Training sessions should be arranged in order to improve and enhance the skills of employed. It has been observed in the present study that HRM practices play mediating role between stakeholder pressure and environmental sustainability. It is in the consideration that all the 10 Energy firms are under the area of study. HRM practices might receive a better response from respondents, that these practices can control the stakeholders' pressure and improve the environmental sustainability. These practices shall be continued and enhanced keeping in pace with the change of environment in Energy firms. It thus strongly recommends that HRM practices should be implemented within the firms in order to control the stakeholder pressure and to complete the task with ease in a given time without any workload pressure and the communication gap between employees and managerial supervisors. According to this research stakeholders' pressure is becoming the hurdle in improving the environmental sustainability. It prevents the firms to introduce new policies and rules which are very beneficial for the firms. In short it is indispensable for organizations to have a strong HR practices system in order to mitigate the negative impact of stakeholders' pressure which may resist toward a sustainable environment.

\section{References:}

.Castelló, I., \& Lozano, J. M. (2011). Searching for new forms of legitimacy through corporate responsibility rhetoric. Journal of Business Ethics, 100(1), 11-29.

Albinger, H. S., \& Freeman, S. J. (2000). Corporate social performance and attractiveness as an employer to different job seeking populations. Journal of Business Ethics, 28(3), 243-253..

Barney, J. (1991). Firm resources and sustained competitive advantage. Journal of management, 17(1), 99-120. 
Rafiq, M., Zhang, X. P., Yuan, J., Saroya, M., \& Kanwal, S. (2019). Translating stakeholder pressure into environmental sustainability-Studying HRM practices as mediating role. Archives of Business Research, 7(10), 89-103.

Baron, R. M., \& Kenny, D. A. (1986). The moderator-mediator variable distinction in social psychological research: Conceptual, strategic, and statistical considerations. Journal of personality and social psychology, 51(6), 1173.

Bask, A., Halme, M., Kallio, M., \&Kuula, M. (2013). Consumer preferences for sustainability and their impact on HRM practices:The case of mobile phones.InternationalJournal of Physical Distribution \& Logistics Management, 43(5/6), 380-406.

Batt, R., \& Banerjee, M. (2012). The scope and trajectory of strategic HR research: Evidence from American and British journals. The International Journal of Human Resource Management, 23(9), 1739-1762.

Bauer, T. N., \&Aiman-Smith, L. (2010). Green career choices: The influence of ecological stance on recruiting. Journal of Business and Psychology, 10(4), 445-458.

Bauer, T. N., Erdogan, B., \& Taylor, S. (2012). Creating and maintaining environmentally sustainable organizations: Recruitment and onboarding.

Boiral, O. (2002). Tacit knowledge and environmental management. Long Range Planning, 35(3), 291-317.

Boon, C., \&Kalshoven, K. (2014). How High-Commitment HRM Relates to Engagement and Commitment: The Moderating Role of Task Proficiency. Human Resource Management, 53(3), 403-420.

Boon, C., \&Kalshoven, K. (2014). How High-Commitment HRM Relates to Engagement and Commitment: The Moderating Role of Task Proficiency. Human Resource Management, 53(3), 403-420.

Boon, C., Paauwe, J., Boselie, P., \& Den Hartog, D. (2009). Institutional pressures and HRM: developing institutional fit. Personnel Review, 38(5), 492-508.

Boxall, P., \&Macky, K. (2009). Research and theory on high-performance work systems: progressing the highinvolvement stream. Human Resource Management Journal, 19(1), 3-23.

Boxall, P., Purcell, J., \& Wright, P. (2007).Human resource management: scope, analysis, and significance. Oxford Handbook of Human Resource Management.

Boxall, P., Purcell, J., \& Wright, P. (2011). Human resource management: scope, analysis, and significance. Oxford Handbook of Human Resource Management

Bret Becton, J., Giles, W. F., \&Schraeder, M. (2008). Evaluating and rewarding OCBs: Potential consequences of formally incorporating organisational citizenship behaviour in performance appraisal and reward systems. Employee Relations, 30(5), 494-514.

Chin, W. W., Marcolin, B. L., \&Newsted, P. R. (2008). A partial least squares latent variable modeling approach for measuring interaction effects: Results from a Monte Carlo simulation study and an electronic-mail emotion/adoption study. Information systems research, 14(2), 189-217.

CHUANG, C. H., \& Liao, H. U. I. (2010). Strategic human resource management in service context: Taking care of business by taking care of employees and customers. Personnel psychology, 63(1), 153-196.

Dipboye, R. L. (2010).Eight outrageous statements about HR science. Human Resource Management Review, 17(2), 96-106.

Djabatey, E. N. (2012). Recruitment and selection practice of organisation: a case study of HFC Bank (GH) Ltd. Unpublished thesis submitted to the Institute of Distance Learning, Kwame Nkrumah University of Science and Technology. Ghana: Kwame Nkrumah University of Science and Technology.

DuBois, C. L., \& Dubois, D. A. (2012).Strategic HRM as social design for environmental sustainability in organization. Human Resource Management, 51(6), 799-826.

Freeman, R. E., Harrison, J. S., Wicks, A. C., Parmar, B. L., \& De Colle, S. (2010). Stakeholder theory: The state of the art. Cambridge University Press.

Garcés-Ayerbe, C., Rivera-Torres, P., \& Murillo-Luna, J. L. (2012). Stakeholder pressure and environmental proactivity: Moderating effect of competitive advantage expectations. Management Decision, 50(2), 189-206.

González-Benito, J., \& González-Benito, Ó. (2010). A study of determinant factors of stakeholder environmental pressure perceived by industrial companies. Business Strategy and the Environment, 19(3), 164-181.

Greenwood, M. (2013). Ethical analyses of HRM: A review and research agenda. Journal of Business Ethics, 114(2), 355-366.

Guerci, M., \&Shani, A. B. (2013).Moving toward stakeholder-based HRM: A perspective of Italian HR managers. The International Journal of Human Resource Management, 24(6), 1130-1150. 
Guerci, M., Bartezzaghi, E., \&Solari, L. (2010). Training evaluation in Italian corporate universities: a stakeholderbased analysis. International Journal of Training and Development, 14(4), 291-308.

Guest, D. E. (2011). Human resource management and performance: still searching for some answers. Human resource management journal, 21(1), 3-13.

Hayes, A. F., \&Scharkow, M. (2013). The relative trustworthiness of inferential tests of the indirect effect in statistical mediation analysis: Does method really matter?. Psychological science, 24(10), 1918-1927.

Henseler, J., Ringle, C. M., \&Sarstedt, M. (2015). A new criterion for assessing discriminant validity in variance-based structural equation modeling. Journal of the Academy of Marketing Science, 43(1), 115-135.

Hosseini, S. M., Jorjafki, G. M., \&Ashrafi,A. M. (2010, July). Notice of Retraction Quality of work life (QWL) and its relationship with performance. In Advanced Management Science (ICAMS), 2010 IEEE International Conference on(Vol. 1, pp. 559-562). IEEE.

Mayrhofer,W.,Sparrow,P.,\& Brewster, C. (2012).European human resource management: a contextualised stakeholder perspective...

Morse, B. J., \&Popovich, P. M. (2009). Realistic recruitment practices in organizations: The potential benefits of generalized expectancy calibration. Human Resource Management Review, 19(1), 1-8.

Nanjundeswaraswamy, T. S., \&Swamy, D. R. (2012). A literature review on quality of work life and leadership styles. International Journal of Engineering Research and Applications, 2(3), 1053-1059.

Renwick, D. W., Redman, T., \& Maguire, S. (2013). Human resource management: A review and research agenda. International Journal of Management Reviews, 15(1), 1-14.

Rethinam, G. S., \& Ismail, M. (2008). Constructs Of Quality Of Work Life: A Perspective Of Information Technology Professionals. European journal of social sciences, 1.

Sarkis, J., Gonzalez-Torre, P., \&Adenso-Diaz, B. (2010). Stakeholder pressure and the adoption of environmental practices: The mediating effect of training. Journal of Operations Management, 28(2), 163-176.

Sarkis, J., Gonzalez-Torre, P., \&Adenso-Diaz, B. (2010). Stakeholder pressure and the adoption of environmental practices: The mediating effect of training. Journal of Operations Management, 28(2), 163-176.

Subramony,M. (2011).Why organizations adopt some human resource management practices and reject others:An exploration of rationales. Human resource management, 45(2), 195-210.

TEFERA, Y. (2014). PRACTICES AND CHALLENGES OF TRAINING POLICY IMPLEMENTATION AT EQUATORIAL BUSSINESS GROUP (EBG) (Doctoral dissertation, ST. MARY'S UNIVERSITY).

Townsend, K., \& Wilkinson, A. (2014). Guest Editors' Note: Time to Reconnect the Silos? Similarities and Differences in Employment Relations and Human Resources. Human Resource Management, 53(2), 203-210.

Vazquez-Brust, D. A., Liston-Heyes, C., Plaza-Ubeda, J. A., \& Burgos-Jiménez, J. (2010).Stakeholders pressures and strategic prioritisation: An empirical analysis of environmental responses in Argentinean firms. Journal of Business Ethics, 91, 171-192.

Vidal-Salazar, M. D., Cordón-Pozo, E., \&Ferrón-Vilchez, V. (2012).Human resource management and developing proactive environmental strategies:The influence of environmentaltrainingandorganizational learning. Human Resource Management, 51(6), 905-934.

Walls, J. L., Berrone, P., \&Phan, P. H. (2012). Corporate governance and environmental performance: Is there really a link?. Strategic Management Journal, 33(8), 885-913.

Yu, W., \&Ramanathan, R. (2015). An empirical examination of stakeholder pressures, green operations practices and environmental performance. International Journal of Production Research, 53(21), 6390-6407.

Zibarras, L., \& Ballinger, C. (2011).Promoting environmental behaviour in the workplace: A survey of UK organisations. Going green: The psychology of sustainability in the workplace, 84-90. 